\title{
Molecular Characterization and Sero-epidemiological Study of Leptospirosis in Cattle of Nagpur and Surrounding Regions
}

\author{
Shilpa L. Moon ${ }^{1}$, Sandeep P. Chaudhari ${ }^{1}$, Nandkishor N. Zade ${ }^{1}$, Wiqar A. Khan ${ }^{1}$, \\ Shilpshri V. Shinde ${ }^{1}$, Nitin V. Kurkure ${ }^{2}$, Sukhdeo B. Barbuddhe ${ }^{3}$, Aanusha Alamuri ${ }^{4}$ \\ and V. Balamurugan ${ }^{4}$ \\ ${ }^{1}$ Department of Veterinary Public Health, Nagpur Veterinary College, \\ MAFSU, Nagpur, Maharashtra, India \\ ${ }^{2}$ Department of Veterinary Pathology, Nagpur Veterinary College, MAFSU, Nagpur, \\ Maharashtra, India \\ ${ }^{3}$ ICAR-National Research Centre on Meat (NRCM), Hyderabad, Telangana, India \\ ${ }^{4}$ ICAR-National Institute of Veterinary Epidemiology and Disease Informatics (NIVEDI), \\ Bengaluru, Karnataka, India
}

*Corresponding author

\begin{tabular}{|l|}
\hline Ke y w or d s \\
Leptospirosis, \\
Cattle, Nagpur, \\
PCR, ELISA, MAT \\
\hline Article Info \\
\hline $\begin{array}{l}\text { Accepted: } \\
12 \text { April } 2019 \\
\text { Available Online: } \\
10 \text { May } 2019\end{array}$ \\
\hline \hline
\end{tabular}

\section{A B S T R A C T}

A zoonotic disease Leptospirosis is caused by pathogen of the genus Leptospira and it is an emerging global public health problem. In the present study a total of 266 cattle blood and sera samples were collected from the towns and villages of Nagpur, Wardha, Bhandara Gadchiroli and Durg districts during December 2017 to 2018 and tested for the presence of Leptospira. These samples were from randomly selected herds with history of repeated breeding, abortion, reproductive disorders, etc. also including some apparently healthy animals. The presence of leptospiral DNA in blood sample was assayed by PCR amplification of rrs (16S rRNA) gene. Antibodies against Leptospira serovars were tested using an enzyme-linked immunosorbent assay (ELISA) and microscopic agglutination test (MAT). Out of 266 blood samples, in 33 samples leptospires DNA was identified with the frequency of $12.40 \%$. A total of 53 cattle sera were positive in commercial Leptospira Bovine Hardjo ELISA kit indicated $19.92 \%$ seroprevalence. In the MAT analysis 120 samples revealed presence of different serovars with the seropositivity $45.11 \%$. The study supports the probable role of cattle in maintaining Leptospira Hardjo along with some other serovars and warrants an intensive control and surveillance programme for reducing leptospirosis in cattle.

\section{Introduction}

Leptospirosis is among the fastest globally reemerging anthropozoonosis caused by pathogenic bacteria of the genus Leptospira. The disease affects a variety of domestic animals viz. cattle, buffalo, sheep, goat, horse and swine which results into heavy economic losses to the farming community (Srivastava, 2008). It is more predominate in tropical countries having high rain fall, humidity, presence of marshy land and paddy grown 
area (Favero et al., 2017). Infection in humans usually results from direct or indirect exposure to the urine of infected animals or healthy carriers, aborted fetus and uterine discharges which may contaminate soil, pasture, drinking water and feed is the main source of infection (Adugna, 2016, Favero et al., 2017). Extreme weather events such as cyclones and floods, increased rainfall associated with global warming are considered as the factors for the increased incidence of leptospirosis in animals and humans (Lau et al., 2010).

Infection of Leptospira organism in cattle can be divided into two groups of strain; stain adapted to bovine and strain adapted to other domestic or wild animal. The serovar mainly associated with cattle is serovar Hardjo however; serovars Pomona, Icterohaemorrhagiae Hebdomadis, Australis, Bankinang and Grippotyphosa can also be associated to bovine leptospirosis (Balamurugan et al., 2018). Leptospira interrogans serovar Hardjo type Hardjobovis is the primary cause of acute and chronic leptospirosis in cattle, and in addition causes persistent infection of kidneys and female reproductive tract (Morey et al., 2006). In bovines, clinical signs are usually mild or inapparent when infected by host-adapted serovars. However, for infections with nonhost-adapted serovars, clinical symptoms may range from mild to severe (Lilenbaum and Martins, 2014). The disease in bovine is responsible for direct or indirect economic losses, which include costs of abortion, stillbirth, infertility, failure to thrive, reduced productivity and decreased milk yield (Quinn et al., 1994). The economic losses to the farming community is also due to associated veterinary costs in domestic and commercial livestock, with potential for malnutrition and impoverishment amongst individuals and communities dependent on animal sources of protein, especially in subsistence economies
(Srivastava, 2008). As per the studies conducted in different parts of the world, the serovar responsible for reproductive losses in case of bovines depends on the type of serovar endemic in that region since leptospiral antibodies may present in the serum for considerable period of time after infection, which indicates the present or part exposure to the leptospiral antigen (Balamurgan et al., 2013). The early identification of carrier animals and information on the shedding state are crucial to prevent the spread of leptospiral infection to other animals and humans. By considering the all these facts the aim of the present study was to characterize Leptospira organism by molecular and serological techniques in the Nagpur and surrounding regions.

\section{Materials and Methods}

\section{Details of samples}

A total of 266 cattle blood and sera samples were collected during the period from December 2017 to December 2018 from Nagpur, Wardha, Bhandara, Gadchiroli and Durg districts. The region of sample collection is located in eastern region of the Indian state of Maharashtra (Nagpur Division). The latitude and longitude of the region is $21^{\circ} 9^{\prime} 36^{\prime \prime} \mathrm{N}, 79^{\circ} 4^{\prime} 48^{\prime \prime} \mathrm{E}$. The area is characterized by a tropical climate with average temperature of $39.22^{\circ} \mathrm{C}$. During monsoon, it is very humid. The samples collected were from randomly selected herds with history of repeated breeding, abortion, reproductive disorders, etc. including some apparently healthy animals. No animal had history of earlier vaccination.

\section{Molecular characterization}

DNA isolation from whole blood of animal samples was carried out as per the method of Martin et al., (2004) with slight modification. 
All DNA extracted from the blood samples tested by PCR amplification using oligonucleotide primers (Lepto A. 5'-GGC GGC GCG TCT TAA ACA TG-3') (Lepto B. 5'-TTC CCC CCA TTG AGC AAG ATT-3') to amplify a 331 base pair fragment of rrs (16S rRNA) gene common to all Leptospires (pathogenic and nonpathogenic) as described by Merien et al., (1992). The PCR was carried out in a PCR tube $(0.2 \mathrm{ml})$ as per the protocol described by Merien et al., (1992) with modifications. A $25 \mu \mathrm{l}$ reaction volume consisting of $2 \mu 1$ of template DNA added to a tube containing $12.5 \mu \mathrm{l}$ of $2 \mathrm{X}$ Master Mix, 1 $\mu \mathrm{l}$ of each primer and $8.5 \mu$ of nuclease free water. Amplification was performed in a thermal cycler (Applied Biosystems, USA) with initial denaturation at $94^{\circ} \dot{\mathrm{C}}$ for $3 \mathrm{~min}$, followed by 40 cycles of denaturation at $94^{\circ} \mathrm{C}$ for $30 \mathrm{sec}$, annealing at $60^{\circ} \dot{\mathrm{C}}$ for $30 \mathrm{sec}$, extension at $72^{\circ} \mathrm{C}$ for $40 \mathrm{sec}$ and then a final extension at $72^{\circ} \mathrm{C}$ for $10 \mathrm{~min}$. Negative (no DNA template) and positive (DNA from Leptospira interrogans) controls were also performed and aliquots were analyzed using $1.5 \%$ agarose gel electrophoresis, stained with ethidium bromide and images were obtained by UV transillumination.

\section{Enzyme Linked Immunosorbent Assay (ELISA)}

A commercial indirect ELISA kit (PrioCHECK $^{\mathrm{TM}}$ L. hardjo Ab Strip Kit) was used for the detection of antibodies against antibodies against Leptospira interrogans serovar Hardjo in serum. Indirect ELISA was performed as per the protocol outlined in the user's manual. The optical density of microwells was read using a micro plate reader (Thermo Scientific ${ }^{\mathrm{TM}}$ ) at a wavelength of 450. ELISA optical density (OD) readings were transformed to serum/positive percentage (PP) according to specific equation cited by manufacture.

\section{Microscopic Agglutination Test (MAT)}

All the sera samples from animals were subjected to MAT at Indian Council of Agricultural Research-National Institute of Veterinary Epidemiology and Disease Informatics (ICAR-NIVEDI), Bengaluru. Serological tests and leptospira culture protocol in this study were based on the standard methodology using a panel of 18 reference serovars. The panel of antigens included L. interrogans serovars Australis (Aus), Bankinang (Aut), Canicola (Can), Sejroe (Sej), Hebdomadis (Heb), Icterohaemorrhagiae (Ict), Pyrogenes (Pyr), Kaup (Kau), Pomona (Pom), Hurstbridge (Hus), Javanica (Jav), Panama (Pan), Copenhageni (Cop), Bataviae (Bat), Djasiman (Dja), Shermani (She) and Grippotyphosa (Grippo). A MAT titre of 1:40 or above was taken as a positive reactor.

\section{Results and Discussion}

The PCR assay used in the present study was genus specific and detected all leptospiral serovars. The results of this study showed a high frequency of Leptospira spp. in the blood samples of cattle. The results of study showed that out of 266 blood samples, $331 \mathrm{bp}$ fragment of rrs gene was amplified in 33 $(12.40 \%)$ samples (Fig. 1). The results of the study revealed the direct detection of Leptospira spp. in the blood of cattle by PCR is useful in rapid identification of carrier animals. PCR has the advantage that it does not require the isolation of the organism and detects DNA from both viable and nonviable organisms (Noubade et al., 2002). The finding of the study supported the findings of Cheema et al., (2007), Jafari et al., (2011) and Patel et al., (2017) who too carried out the investigation on field samples.

In present study Leptospira spp. serovar Hardjo is present with a prevalence of $19.92 \%$ 
(53/266) in cattle despite the lack of reports on clinical cases of the disease. It is therefore possible that losses from leptospirosis in the cattle population in this region may be underestimated as there is evidence from a number of countries including India that serovar Hardjo continues to cause substantial reproductive losses in cattle through abortion and infertility. In similar studies by using the same Leptospira Bovine Hardjo kit, the different rate of seroprevalence was reported for leptospirosis in various Indian states such as Maharashtra (30.40\%), Gujarat (13.50\%), Punjab (3.70\%), Tamil Nadu (50\%), Haryana
(4.46\%), Telangana (4\%), Jharkhand (10\%), Karnataka (16.66\%) and Chhattisgarh (23.68\%) (Balmurugan et al., 2016). Moreover, in some of the countries also serovar hardjo was found to be most prevalent i.e. in Arizona, USA (Songer et al., 1983), Malaysia (El Jalii, 2008), Turkish (Kocabiyik and Cetin, 2004), Iraq (Al-Badrawi et al., 2010) and Brazil (Mineiro et al., 2011). Besides being an important cause of bovine abortion, reduced fertility and agalactia, serovar Hardjo also poses a potential zoonotic threat to humans who are exposed to infected cattle (Balmurugan et al., 2016).

Fig.1 Agarose gel PCR products

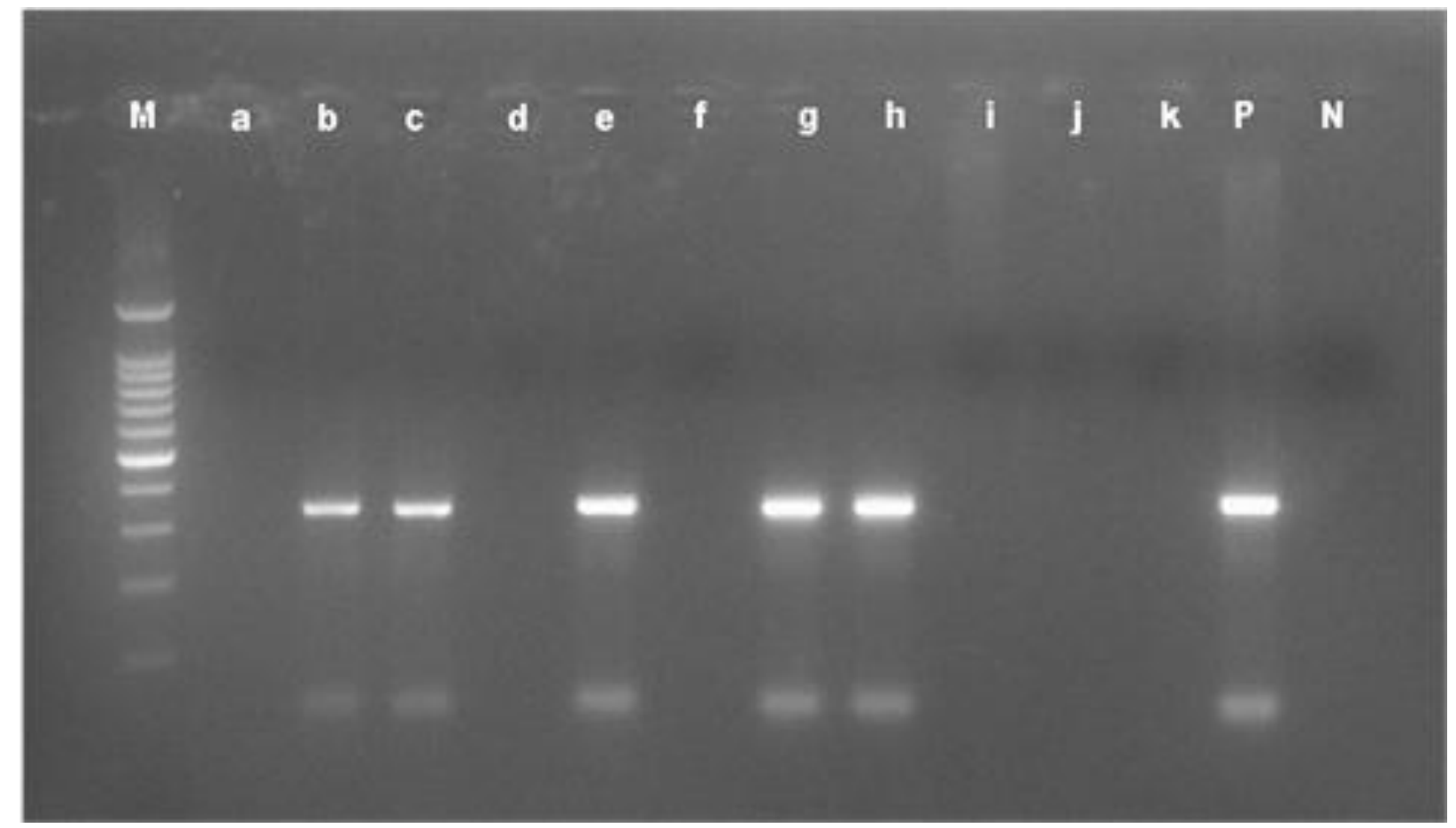

Lane M: 100 bp DNA Ladder

Lane P: Positive control (331 bp),

Lane N: Negative control,

Lane a, d, f, i, j, k: Negative samples

Lane b, c, e, g, h: Positive samples

In cattle out of 266 sera screened, 120 sera were positive for with one or more serovars with an overall seroprevalence rate of $45.11 \%$. The highest seropositivity was recorded against serovar Panama (30.83\%) followed by Hebdomadis (25.83\%), Javanica (25\%), Icterohaemorrhagiae (18.33\%), Djasiman (17.5\%), Sejroe (12.5\%), Bataviae (10.83\%), Hurstbridge (10\%), Australis (8.33\%), Automnalis (8.33\%), Copenhageni 
(7.5\%), Kaup (7.5\%), Pomona (7.5\%), Canicola (5.83\%), Shermani (5.43\%), Grippotyphosa (5\%) and Pyrogenes (4.16\%). The higher prevalence of these serovars in this study could be explained by the fact that the cattle had close contact with the reservoirs of this serovar. In addition, the longer immune response induced by this serovar and the higher frequency of new infections with this serovar may account for the observed results, as suggested by Guitin et al., 2001. This study supports that bovines may have a role in maintaining different serovars, apart from being a well-known reservoir for Hardjo serovar in cattle in study region. The available literatures did not reveal any such studies in this region. In India a number of different serovars had been reported from time to time from the different states such as serovars Pomona, Hebdomadis, Medanensis, Hardjo, Andamana and Saxkoebing from Andhra Pradesh (Mrunalini et al., 2000), Grippotyphosa, Pomona and Icterohemorhagiae from Andaman and Nicobar (Varma et al., 2001), Hardjo, Bataviae, Canicola, and Australis from West Bengal (Mandal et al., 2008), Icterohaemorrhagiae and Grippotyphosa from Uttar Pradesh (Sachan et al., 2011) and Pomona in cattle of various South Gujarat district (Patel et al., 2014) during different survey. Several factors such as herd size, cograzing with infected cattle, access to contaminated water sources, use of infected bulls, inadequate husbandry practices, and replacement with animals from other farms have been found to be associated with leptospiral infections in cattle (Lilenbaum and Santos, 1996; Guitian et al., 2001; Aslantas and Ozdemir, 2005).

In conclusion, in agreement with similar studies, the results obtained from the present study revealed that direct detection of Leptospira spp. in the blood samples of carriers by PCR is useful in rapid identification of carrier animals. Significant prevalence of Leptospira Hardjo serovar in the organised dairy farms of this region proves the endemicity of this serovar in dairy cattle. High prevalence of different leptospiral serovars in apparently healthy bovine in this region indicates the presence of the agent in the environment which may be a potential zoonotic risk to animal hadlers, milkers, and other domestic species in the farm. This study warrants the need for continuous monitoring of Leptospira burden in animals and human in close proximity to each other to combat the zoonotic infection.

\section{Conflict of interest}

No conflicts of interests are declared by authors for the contents in the manuscript.

\section{Acknowledgment}

We are thankful to the ICAR, New Delhi for providing funds under Niche Area Excellence Project on "Center for Zoonoses" in the Department of Veterinary Public Health, Nagpur Veterinary College, Nagpur. We are also thankful to ICAR-National Institute of Veterinary Epidemiology and Disease Informatics (NIVEDI), Bengaluru, Karnataka, India.

\section{References}

Adugna, S. 2016. A Review of Bovine Leptospirosis. European Journal of Applied Sciences, 8:347- 355.

Al-Badrawi, T.Y.G., Habasha, F.G. and Sultan, S.H. 2010. Serological study of Leptospirosis in cattle, sheep and goats in Baghdad Province. Al-Anbar Journal of Veterinary Sciences 3:78-82.

Aslantas, O. and Ozdemir, V. 2005. Determination of the Seroprevalence of Leptospirosis in Cattle by MAT and ELISA in Hatay, Turkey. Turkish Journal of Veterinary \& Animal Sciences, 
29:1019-1024.

Balamurugan, V., Alamuri, A., Bharathkumar, K. Patil, S.S., Govindaraj, G.N., Nagalingam, M., Krishnamoorthy, P., Rahman, H. and Shome, B.R. 2018. Prevalence of Leptospira serogroup specific antibodies in cattle associated with reproductive problems in endemic states of India. Tropical Animal Health and Production. DOI.org/10.1007/s11250-018-1540-8.

Balamurugan, V., Thirumalesh, S.R.A., Sridevi, R., Mohandoss, N., Govindaraj, G., Hemadri, D., Gajendragad, M.R. and Rahman, H. 2013. Seroprevalence of Bovine Leptospirosis in Odisha, India. World Journal of Veterinary Science, 1:17.

Balamurugan, V., Thirumalesh, S.R.A., Veena, S., Alamuri, A., Nagalingam, M., Sridevi, R., Govindaraj, G., Hemadri, D., Gajendragad, M.R., Rahman, H. 2016. Investigation on the distribution of Leptospira serovars and its prevalence in bovine in Konkan region, Maharashtra, India. Journal of Advanced Veterinary and Animal Research 4(2):19-26.

Cheema, P.S., Srivastava, S.K., Amutha, R., Singh, S., Singh, H. and Sandey, M. 2007. Detection of pathogenic leptospires in animals by PCR based on lipL21 and lipL 32 genes. Indian Journal of Experimental Biology, 45:568 - 573.

El Jalii, I.M. 2008. Comparison between ELISA and the Microscopic Agglutination Test for the Diagnosis of Bovine Leptospirosis. Revue d'elevage et de medicine Veterinaire des Pays Tropicaux, 61(2):73-75.

Favero, J.F., Araujo, H.L., Lilenbaum W., Machado G., Tonin A.A., Baldissera M.D., Stefani L.M. and Silva, A.D. 2017. Bovine leptospirosis: Prevalence, associated risk factors for infection and their cause-effect relation. Microbial Pathogenesis, 107:149-154.

Guitian, F.J., Garcia-Pena, F.J., Oliveira, M.L., Sanjuan, M.L. and Yus, E. 2001. Serological study of the frequency of leptospiral infections among dairy cows in farms with suboptimal reproductive efficiency in Galicia, Spain. Veterinary Microbiology, 80: 275-284.

Jafari, D.A., Shahbazkia, H.R. and Ronagh, N. 2011. Evaluation of pathogenic serovars of Leptospira interrogans in dairy cattle herds of Shahrekord by PCR. Indian Journal of Microbiology, 3(3): 135-139.

Kocabiyik, A.L. and Cetin, C. 2004. Bovine leptospirosis in south Marmara region of Turkey: A serological survey. Revuede Medecine Veterinaire, 155(12): 606-608.

Lau, C. L, Smythe, L. D., Craig, S. B. and Weinstein, P. 2010. Climate change, flooding, urbanisation and leptospirosis: fuelling the fire? Transactions of the Royal Society of Tropical Medicine and Hygiene, 104(10):631-638. doi: 10.1016/j.trstmh.2010.07.002. Epub 2010 Sep 1.

Lilenbaum, M. and Santos, M.R.C. 1996. Effect of management systems on the prevalence of bovine leptospirosis. VetRecord, 138: 570-571.

Lilenbaum, W. and Martins, G. 2014. Leptospirosis in cattle: a challenging scenario for the understanding of the epidemiology. Transboundary and Emerging Diseases, 61(1): 63-68. doi: 10.1111/tbed.12233.

Mandal, S., Joardar, S.N., Chakraborty, D. and Sardar, N. 2008. Seroepidemiological study of bovine leptospirosis in West Bengal. Indian Journal of Comparative Microbiology, Immunology and Infectious Diseases, 29(1\&2): 42-44.

Martin L. F., Philippot L., Hallet S., Chaussod R., Germon J. C., Soulas G., and Catroux G. 2001. DNA extraction from soil: old bias for new microbial diversity analysis methods. Applied Environmental Microbiology, 67:2354-2359.

Merien, F., Amouriauz, P., Perolat, P., Barnaton, G. and Saint Girons, I. 1992. Polymerase chain reaction for detection Leptospira spp. in clinical samples. Journal of Clinical Microbiology, 30: 2219-2224. 
Mineiro, A.L.B.B., Vieira, R.J., Costa, E.A., Santos, R.L., Gonçalves, L.M.F., Carvalho, S.M., Bomfim, M.R.Q. and Costa, F.A.L. 2011. Serology, polymerase chain reaction and histopathology for leptospirosis in samples collected at slaughter from dairy cows of Parnaiba region, State of Piaul, Brazil. Pesq. Veterinaria Brasileira, 31(10):859-866.

Morey, R.E., Galloway, R.L., Bragg, S.L., Steigerwalt, A.G., Mayer, L.W. and Levett, P. N. 2006. Species-Specific Identification of Leptospiraceae by $16 \mathrm{~S}$ rRNA Gene Sequencing. Journal of Clinical Microbiology, 44(10): 3510 3516.

Mrunalini, N. and Ramasastry, P. 2000. A note on seroprevalence of subclinical leptospirosis in organised farms in Andhra Pradesh. Indian Veterinary Journal, 77(8):713-714.

Noubade, R., Krishnamurthy, G.V., Murag, S., Venkatesha, M.D. and Krishnappa, G. 2002. Differentiation of pathogenic and saprophytic leptospires by polymerase chain reaction. Indian Journal of Medical Microbiology, 20: 33-36.

Patel, J. M., Vihol, P. D., Prasad, M. C., Kalyani, I. H., Raval, J. K., Patel, K. M., Thirumalesh, S. R. A. and Balamurugan, V. 2014. Seroepidemiological pattern of leptospirosis in bovine of South Gujarat, India. Veterinary World, 7(11): 999-1003.
Patel, J. M., Vihol, P.D., Prasad, M.C., Patel, J.H., Raval J.K. and Kalyani, I.H. 2017. Polymerase Chain Reaction in the Diagnosis of Spontaneous Leptospirosis in Bovines. International Journal of Current Microbiology and Applied Sciences, 6(12):1723-1728.

Quinn, P.J., Carter, M.E., Markey, B. and Carter, G.R. 1994. Clinical Veterinary Microbiology, Wolfe Publ. Ltd., Spain; 296-303.

Sachan, N., Binita N., Singh, V.P., Sabrinath, T., Chaudhary, P. and Agarwal, R.K. 2011. Seroprevalence of leptospirosis in the animals in Rohilkhand region of Uttar Pradesh, India. International Journal Agro Veterinary Medicine Science, 5(6):511-519.

Songer, J.G.; Chilelli, C.J.; Marshall, M.M.; Noon, T.H. and Meyer, R. 1983. Serological survey for leptospirosis in Arizona beef cattle in 1981. American Journal of Veterinary Research, 44:17631764.

Srivastava, S.K. 2008. Current status of leptospirosis in India in animals and humans. Indian Journal of Veterinary Pathology, 32(2):179-186.

Varma, A., Rai, R.B., Balakrishnan, P., Gupta, A. and Naveen K.A. 2001. Seroprevalence of leptospirosis in animas of Andaman and Nicobar islands. Indian Veterinary Journal, 78:936-937.

\section{How to cite this article:}

Shilpa L. Moon, Sandeep P. Chaudhari, Nandkishor N. Zade, Wiqar A. Khan, Shilpshri V. Shinde, Nitin V. Kurkure, Sukhdeo B. Barbuddhe, Aanusha Alamuri and Balamurugan, V. 2019. Molecular Characterization and Sero-epidemiological Study of Leptospirosis in Cattle of Nagpur and Surrounding Regions. Int.J.Curr.Microbiol.App.Sci. 8(05): 1457-1463. doi: https://doi.org/10.20546/ijcmas.2019.805.167 